\title{
Water, sanitation and hygiene (WASH) Promotion: A qualitative analysis of experiences of stakeholders in rural KwaZulu-Natal
}

Chanelle Mulopo ( $\nabla$ cmulopo@gmail.com )

University of KwaZulu-Natal College of Health Sciences https://orcid.org/0000-0001-6412-3200

Moses J Chimbari

University of KwaZulu-Natal College of Health Sciences

Keywords:

Posted Date: December 24th, 2019

DOl: https://doi.org/10.21203/rs.2.19565/v1

License: (c) (1) This work is licensed under a Creative Commons Attribution 4.0 International License.

Read Full License 


\section{Abstract}

The authors have requested that this preprint be removed from Research Square. 